\title{
LAS FRONTERAS DEL REINO DE VALENCIA EN TIEMPOS DE JAIME ॥
}

\author{
José HINOJOSA MONTALVO \\ Universitat d'Alacant
}

En el mes de febrero de 1245 Jaime I se apoderaba de la plaza de Biar, con lo que prácticamente se daba por finalizada la conquista de las tierras valencianas de Sharq al-Andalus, llegándose a los límites fijados con Castilla para repartirse los territorios musulmanes en anteriores pactos de Tudilén, Cazola y el reciente de Almizrra en 1244', en el que se delimitaba la frontera entre las Coronas de Castilla y de Aragón. Ello no quiere decir que el nuevo reino de Valencia, nacido por la voluntad expresa de Jaime el Conquistador, mantuviera unos límites inamovibles en el tiempo, sino todo lo contrario, ya que a lo largo de dos siglos más se fueron incorporando nuevos espacios territoriales, en particular las comarcas del Alacantí, el alto y el bajo Vinalopó y el bajo Segura, durante el reinado de Jaime $\mathrm{ll}$, en lo que supuso la mayor ampliación territorial del reino desde tiempos de Jaime I.

No vamos a entrar en el análisis pormenorizado del trazado de esta frontera entre Biar y Busot, puesto que disponemos de detallados estudios de J.M. Del Estal2, J. Ferrándiz Lozano y el más reciente de E. Guinot en el que analiza los límites del reino de Valencia a lo largo de su historia ${ }^{3}$. Estos límites no respondían a un trazado caprichoso, como pretendía Giménez Soler a principios de este siglo ${ }^{4}$, sino que repo-

1 FERNÁNDEZ LOZANO, José, Data Almizrrano... Siete siglos y medio de historiografía valenciana sobre el Tratado de almizrra (1244-1994), Alicante, 1994.

2 DEL ESTAL, J.M., «Delimitación del término municipal de la villa de Alicante por Alfonso $X$ el Sabio y Jaime II de Aragón (1252-1296)", Item, n. 1, pp. 96-109; Conquista y anexión de las tierras de Alicante, Elche, Orihuela y Guardamar al Reino de Valencia por Jaime /l de Aragón (1296-1308), Alicante, 1982.

3 GUINOT, E., Els límits del regne, Valencia, 1995, cap. 4, pp. 43-76.

4 GIMÉNEZ SOLER, A., "La Corona de Aragón y Granada», Boletín de la Real Academia de Buenas Letras de Barcelona, julio a septiembre de 1905, pp. 106-107. 
saban sobre unos antecedentes históricos y unas bases geográficas, esto es, la separación entre la parte montañosa y el llano de las tierras que hoy configuran la actual provincia de Alicante. En palabras de E.A. Llobregat «la frontera estuvo en función de la distinción entre llano y montaña $»^{5}$, visible para cualquier observador del panorama que se otea desde la cima del castillo de Santa Bárbara en Alicante. La sierra de Alcoy, las de Penya Rubia, l'Arguenya, el Carrascar, el Maigmó y la de Busot eran la barrera que separaba los reinos de Valencia y de Murcia desde 1245.

Aunque la configuración territorial del reino de Valencia no quedará cerrada de forma definitiva hasta finales del siglo XIV, la realidad de 1245 era que la monarquía consideraba finalizada su intervención de conquista en tierras valencianas y el nuevo reino aparecía dotado de unos límites, mencionados expresamente en 1240 en la versión latina de los Furs y de facto, como señala Guinot, tras la ocupación de Biar en febrero de 1245.

En años posteriores, durante el reinado de Jaime I, se fue perfilando la frontera del reino de Valencia en sus zonas limítrofes con Cataluña, Aragón y Castilla, en concreto con este último reino en el tramo desde el Rincón de Ademuz hasta Villena, que eran las zonas con lugares de adscripción más confusa ${ }^{6}$. En cambio la frontera de Valencia con Murcia permaneció inalterada, manteniéndose lo estipulado en el pacto de Almizrra, que incluía para el reino de Valencia las localidades de Biar, Castalla, Tibi, Jijona, Relleu, Orxeta y Finestrat. El barranco del Carritjar, entre las actuales poblaciones de Vila Joiosa y El Campello, marcaba el límite septentrional del término de Alicante y, por tanto, del reino de Murcia.

Las luchas internas y la guerra civil en que se debatió Castilla entre Fernando IV, hijo de Sancho el Bravo, y los infantes de la Cerda, descendientes del primogénito de Alfonso X, permitieron a Jaime II incorporar entre 1296-1304 el reino de Murcia, concedido como recompensa a cambio de la ayuda militar al pretendiente Alfonso de la Cerda. Los trabajos eruditos y detallados de J.M. Del Estal y $\mathrm{M}^{\mathrm{a}} \mathrm{T}$. Ferrer i Mallol ${ }^{7}$ han permitido reconstruir con todo detalle la campaña militar y de ocupación llevada a cabo por Jaime II, testimonio de la vitalidad del reino de Aragón frente a la anarquía castellana y culminación de una expansión territorial anhelada por los monarcas aragoneses y que sólo ahora, ante coyuntura tan propicia, pudo llevarse a cabo. Además de una situación política favorable, influyó también la aceptación mayoritaria de los grupos dirigentes de los más importantes núcleos urbanos murcianos, cuyo sentido «pa-

5 LLOBREGAT, E.A., "Castillos y fronteras medievales en la provincia de Alicante», Castillos de

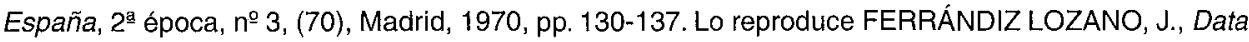
almizrrano, p. 96.

6 GUINOT, E., Els límits del regne, capítulos 4, 5 y 6 analiza con todo detalle estas rectificaciones territoriales de la frontera valenciana durante la segunda mitad del siglo XIII.

7 DEL ESTAL, J.M., Conquista y anexión de las tierras de Alicante, Elche, Orihuela y Guardamar al reino de Valencia por Jaime I/ de Aragón (1296-1308), Alicante, 1982; Corpus documental del reino de Murcia bajo la soberania de Aragón 81296-1304/5) l/1, Alicante, 1985 y l/2, Alicante, 1990; FERRER I MALLOL, M‥T., “Notes sobre la conquesta del regne de Múrcia per Jaume II (1296-1304/4)", Homenatge a la memòria del prof. Emilio Sáez. Aplec d'estudis dels seus deixebles i col-laboradors, Barcelona, Universitat-Institució Milà i Fontanals, 1989, pp. 27-44. 
triótico" se apelaba, ya que la mayoría eran oriundos de la Corona de Aragón, así como las garantías de respetar la independencia y neutralidad de las encomiendas de la Orden de Santiago, o la del ra'is de Crevillente, Muhammad Abenhudell, y las de don Juan Manuel.

Sin embargo, una serie de factores aconsejaron y llevaron a Jaime II a buscar la paz: la legitimación de Fernando IV, lo que descartaba la candidatura de Alfonso de la Cerda; la muerte del rey de Granada Muhammad II y el ascenso de Muhammad III, que firmó la paz con Castilla; la rebelión nobiliaria en Aragón, algunos de cuyos miembros más destacados animaban al rey a la paz. Por su parte Fernando IV de Castilla hubo de renunciar a parte del reino de Murcia en aras de pactar con Jaime II, frente a la postura de su madre, María de Molina, partidaria de recuperar todo el reino.

En Torrellas, localidad en la falda del Moncayo, se reunieron el infante don Juan, por Castilla; don Jimeno de Luna, arzobispo de Zaragoza, en representación de Aragón y como árbitro imparcial el rey de Portugal don Dionís. El 8 de agosto de 1304 se firmó la sentencia arbitral que dividía el reino de Murcia en dos partes, fijando como frontera divisoria el bajo Segura, salvo Guardamar y Cartagena, a pesar de estar ubicados en la parte derecha y que ha dado lugar a que algunos autores lo interpretaran como un desconocimiento de la geografía del país por parte de la comisión arbitral. Pero la documentación de la época pone de manifiesto que no había tal desconocimiento sino un conflicto de intereses entre las partes, sobre todo por parte del infante don Juan Manuel, cuyo señorío de Elche había perdido, y la negativa de Castilla, inflexible en mantener Yecla para su corona, por ser villa del citado infante 8 .

El mayor problema radicaba en que la sentencia dejaba sin precisar los límites entre el Segura y Villena, lo que provocó disensiones entre las partes por la adscripción de localidades como Yecla, Abanilla, Jumilla, etc. por lo que hubo que nombrar una nueva comisión para resolver tales diferencias, integrada por el canciller mayor de Fernando IV, Diego García de Toledo, y Gonzalo García por parte de Jaime II. El resultado fue el acuerdo de Elche el 19 de mayo de 1305, en el que la nueva frontera quedaba fijada así: "partiendo de las proximidades de la actual Venta de la Encina, proseguía hacia el sur por el límite comunal que separaba Villena de Almansa, continuaba luego por el de Caudete con Almansa, bordeando después por el sureste por entero el amplio alfoz de Yecla, que se reservaba para Castilla, proseguía a continuación el término comunal de Yecla con Jumilla, para seguir luego el término de Jumilla con Ontur, Tobarra, Hellín y Cieza, para descender seguidamente al Segura, entre los términos de Fortuna y Orihuela, buscando luego el litoral marítimo, entre los concejos de Murcia y Orihuela, alcanzando el Mediterráneo aproximadamente por el límite interprovincial de Alicante y Murcia en la actualidad, entre Pilar de la Horadada y San Pedro del Pinatar" ${ }^{9}$.

8 Puede verse un análisis detallado de las mencionadas sentencia de Torrellas y acuerdo de Elche en la obra de DEL ESTAL, J.M., Conquista y anexión, pp. 274-282; GUINOT, E., Els límits del regne, pp. 103-115.

9 DEL ESTAL, J.M., «Historia política", en Historia de la provincia de Alicante, Murcia, 1985, p. 228. 
Desde ahora la frontera del reino va a experimentar un salto formidable, desde las sierras de Alcoy, que pasan a ser una frontera interior, administrativa, las comarcas deçà Sexona, a la huerta de Orihuela. La montaña frente al llano. Como núcleos de población más importantes figuraban Orihuela, Alicante y Elche, todos ellos con población mayoritariamente cristiana en tiempos de Jaime II, aunque contaban con morerías urbanas, siendo mayoría la población musulmana en el valle de Elda. El poblamiento de esta zona meridional anexionada a Valencia también presentaba diferencias respecto a las tierras norteñas, pues Alfonso $X$ había dotado a Alicante $y$ Orihuela de extensos alfoces, siguiendo el modelo repoblador castellano, en los que se diseminaban diversas alquerías dependientes del municipio rector. Con la incorporación de esta parte del reino de Murcia el rey de Aragón se convirtió también en el dueño de la mayor parte del territorio, ya que Alicante, Orihuela y Guardamar se incorporaron al realengo, aunque no por mucho tiempo, pues años después pasaron a formar parte de los estados del infante Fernando.

Tras la Sentencia arbitral de Torrellas (1304) y el Acuerdo de Elche (1305) el antiguo reino de Murcia quedó dividido en dos sectores: el septentrional bajo la soberanía aragonesa, y el meridional, con su capital Murcia, bajo la de Castilla. Para las comarcas anexionadas por Jaime II comenzó una etapa de valencianización, las búsqueda de un nombre y de una identidad propios, en unos tiempos en que todavía la repoblación no estaba finalizada y los trasiegos de población hacia el Sur eran constantes.

$\mathrm{M}^{\mathrm{a}}$.T. Ferrer ha desbrozado con minuciosidad las denominaciones que la Corona aplicó a estas tierras meridionales alicantinas, al principio definidas como «terre nostre quam habemus ultra Sexonam ${ }^{10}$. La primera línea frontera en Jijona siguió actuando como límite administrativo durante toda la Edad Media: deçà y dellà Sexona. Las aspiraciones de Orihuela a erigirse en capital del territorio, claras ya desde 1307, se vieron cumplidas cuando se creó la gobernación general de Orihuela años más tarde.

La solución final adoptada por Jaime II fue la de encuadrar administrativamente estas tierras en el reino de Valencia entre 1296-1304 en una procuración general enllà Sexona, regida por un Procurator regni Valencie et terre ultra Sexonam, mientras que un baile general ultra Sexonam se encargaba de administrar el patrimonio regio a través de lo que sería la bailía general de Orihuela. La anexión formal de la procuración de Orihuela al reino de Valencia tuvo lugar el 17 de junio de 1308 con la aplicación de los Furs de Valencia como norma legal de todo el territorio, aunque respetando los fueros propios que disfrutaban de la anterior etapa castellana ${ }^{11}$.

Lo cierto es que para propios y extraños estas tierras siguieron teniendo un carácter ambiguo, impreciso, durante buena parte del siglo XIV y en la Crónica de Ramón Muntaner o en la de Pedro el Ceremonioso se las sigue denominando como «regne de Múrcia», como también aparece en documentos de la cancillería real de mediados

10 FERRER I MALLOL, Ma.T., Organització i defensa d'un territori fronterer: La governació d'Oriola en el segle XIV, Barcelona, Institució Milà i Fontanals, 1990, pp. 4-9.

11 DEL ESTAL, J.M., Conquista y anexión, pp. 296-302; FERRER I MALLOL, Ma.T., Organització i defensa, pp. 9-12. 
de siglo, y la antigua frontera de Biar-Castalla-Jijona, seguía teniendo plena vigencia, sobre todo desde el punto de vista de la organización militar del territorio, visible perfectamente en la guerra de los dos Pedros. Estoy de acuerdo con $\mathrm{M}^{\mathrm{a}}$. T. Ferrer cuando afirma que el traspaso del nombre de Valencia a las tierras segregadas del reino de Murcia fue lento, y sólo los fueros, la moneda y las Cortes eran comunes a todo el reino, ya que la administración, el gobierno y la defensa eran independientes en la procuración/gobernación de Orihuela. Medio siglo bajo la Corona de Castilla y los repobladores de origen castellano habían dejado su huella en el territorio, lo hacía diferente, y ello no se borraba de un plumazo. Los reyes de Aragón, por su parte, no lo intentaron nunca, sino que fueron respetuosos con esta personalidad, y a lo largo del siglo XIV vemos como Murcia se castellaniza, mientras Orihuela se valencianiza, aunque siempre quiso mantener su independencia entre ambas capitales. Luego vendría la rivalidad con la emergente Alicante, que también quería ser capital. Pero esta es ya otra historia.

\section{LA FRONTERA CON EL REINO DE GRANADA}

El avance territorial experimentado por el reino de Valencia durante el reinado de Jaime II planteó una nueva realidad fronteriza en el devenir histórico de Valencia, no sólo frente a Castilla, sino frente al Islam granadino, que hasta entonces había quedado relativamente lejano del originario reino de Valencia. A partir de ahora los condicionamientos geoestratégicos y políticos de Valencia con respecto a Granada cambiarán radicalmente, por tierra y por mar, debido al acercamiento físico de la frontera entre ambos reinos. Cierto es que no hubo una frontera directa entre Valencia y Granada, pues el reino de Murcia se interponía entre ambos, pero para las gentes de la época, incluida la monarquía, la frontera, como señala Ferrer i Mallol «era tot el territori que podia ésser amenaçat per una razzia granadina de cinc o sis dies de durada, entre anar i tornar, o pels escamots d'almogàvers, lladres de bestiar i segrestadors de persones». Por tanto podemos hablar con rigor histórico del término frontera, ya que así la utilizaban también las fuentes de la época.

La frontera no fue sólo política sino que tuvo también un variado componente de cariz religioso, económico, social, lingüístico, cultural, etc. cuyo objetivo, como señala Díaz Borrás, no era otro que el arrinconamiento progresivo de las masas musulmanas en beneficio de los planteamientos cristianos ${ }^{12}$, y los moros valencianos fueron conscientes de ello, como pusieron de manifiesto con las armas en la mano en las revueltas del siglo XIII, o de forma silenciosa con la huida clandestina o su marcha a Granada con los ejércitos nazaríes al regreso de sus incursiones por tierras valencianas.

Los recientes estudios, tanto desde la vertiente castellana como desde la granadina, han permitido conocer mejor la problemática político-militar, así como los problemas económicos o sociales generados en torno a la frontera murciana con el reino de

12 DÍAZ BORRÁS, A., Los orígenes de la piratería islámica en Valencia. La ofensiva musulmana trecentista y la reacción cristiana, Barcelona, 1993, p. XIV. 
Granada $^{13}$, pero en el caso del reino de Valencia el panorama historiográfico no presenta un balance tan completo, en buena parte porque el tema sólo ha suscitado el interés de los investigadores de forma consciente y con una metodología adecuada en tiempos recientes ${ }^{14}$, aunque ya el gran cronista que fue P. Bellot, en sus Anales de Orihuela ${ }^{15}$ describió con bastante minuciosidad las incursiones granadinas en tierras de la gobernación de Orihuela, la política municipal de rescate de cautivos, las relaciones entre el consistorio oriolano y localidades como Vélez o Baza, por ejemplo, basándose siempre en las actas municipales de la segunda mitad del siglo XIV y XV, pero dentro de un proyecto de historia en forma de anales, simpiemente narrativo $y$ sin ningún espíritu crítico, sin extraer ninguna conclusión.

Aunque existe documentación relativamente abundante, desde Crónicas a cartas reales y actas municipales, ésta es básicamente cristiana, con escasa aportación granadina, por lo que la visión que se obtiene de la frontera es parcial y «oficial», y si sólo hacemos caso de ella obtendremos una impresión deformada, cuando no sesgada, de lo que fue la frontera. Tengamos en cuenta que a las autoridades cristianas les preocupaba sobre todo la actividad bélica de los jinetes granadinos y sus consecuencias en territorio valenciano, y sólo cuando éstas fueron más importantes o la sensación de peligro fue mayor las fuentes se explayaron un poco más. Las relaciones bélicas entre aragoneses y granadinos en los doscientos cincuenta años de existencia del reino nazari de Granada, fracasado el proyecto de cruzada contra Almería, se redujeron básicamente a correrías y golpes de mano por ambos bandos, con mayor o menor fortuna, pero en ningún caso se buscaban conquistas territoriales sino botín, sobre todo humano, cautivos, que luego serían utilizados por ambos bandos como fuerza de trabajo, instrumento de trueque o fuente de ingresos a través de los rescates ${ }^{16}$.

Pero la frontera no generó tan sólo una actividad bélica. Hoy, todos cuantos nos acercamos desde una $u$ otra perspectiva a la historia de Granada y de sus vecinos

13 TORRES FONTES, J., "La actividad bélica granadina en la frontera murciana (SS. XIII-XV)», Príncipe de Viana. Homenaje a José Maria Lacarra, anejo 3, 1986, año XLVII, pp. 721-738;

JIMÉNEZ ALCÁZAR, Juan F., "El hombre y la frontera: Murcia y Granada en época de Enrique IV", Miscelánea Medieval Murciana, XVII, 1992, pp. 77-96.

14 RUZAFA GARCÍA, M., "La frontera de Valencia con Granada: la ruta terrestre (1380-1440)", Andalucía entre Oriente y Occidente (1236-1492). Actas del V Coloquio de Historia Medieval de Anda* lucía, Córdoba, 1988, pp. 659-672.

15 BELLOT, P., Anales de Orihuela (siglos XIV-XVI), Edic. preparada por J. TORRES FONTES, Orihuela, 1954.

16 HINOJOSA MONTALVO, J., "Tácticas de apresamiento de cautivos y su distribución en el mercado valenciano (1410-1434)», Qüestions valencianes, I, Valencia, 1979, pp. 5-44; "Cristianos, mudéjares y granadinos en la gobernación de Orihuela", IV Coloquio de historia medieval andaluza, Almería, 1988, pp. 323-342; DÍAZ BORRÁS, A., Los orígenes de la piratería islámica en Valencia. La ofensiva musulmana trecentista y la reacción cristiana, Barcelona, 1993; "Notas sobre los primeros tiempos de la atención valenciana a la redención de cautivos cristianos (1323-1339)", Estudis Castellonencs, 3 , (1986), pp. 147-171; FERRER I MALLOL, Mª.T., «La redempció de captius a la Corona catalano-aragonesa", Anuario de Estudios Medievales, 15, (1985), pp. 237-298. 
cristianos, somos conscientes de que, frente a la imagen distorsionada e interesada de guerra y enfrentamiento con que se quiso presentar este periodo, lo que predominó fue la paz sobre la guerra, la tregua frente al episodio bélico, lo que no excluye que en torno a la frontera se articulara todo un amplio espectro de relaciones sociales y económicas, una mentalidad, la del hombre de frontera, tan peculiar, un paisaje natural moldeado por el hombre, una psicosis o «neurosis granadina», como la calificó J.E. López de Coca, que perduró largo tiempo en los ámbitos fronteros del mediodía valenciano y sobre la que todavía hay que seguir investigando.

Para Torres Fontes la línea fronteriza entre Murcia y Granada estuvo jalonada por una serie de fracasos en el tiempo, desde el fracaso en el intento por mantener la línea del Almanzora, señalada en el tratado de Alcaraz en 1243, al fracaso de la alianza entre Castilla y Aragón contra Granada, y también, que es lo que ahora nos interesa, a lo que considera como fracaso de Jaime II en su intento de anexionar el reino de Murcia a la Corona de Aragón y de llevar la frontera aragonesa al Almanzora, «recuperando la vecindad granadina tan provechosa para sus intereses políticos y económicos" ${ }^{17}$.

En tiempos de Jaime II, a principios del siglo XIV, el reino de Murcia varió mucho en su desarrollo histórico con relación a Granada y a Aragón, pues el área geográfica del reino, que iba desde Biar y el valle de Ayora a la cuenca del Almanzora, se vería reducida por las anexiones de Jaime II en tanto que las emigraciones de los mudéjares murcianos y las posteriores incursiones de los meriniés africanos provocaron un descenso demográfico y una concentración de la población cristiana en los recintos amurallados, despoblándose los campos, lo que no hizo sino favorecer las correrías granadinas por los reinos de Murcia y Valencia. Porque, como ya dijimos, aunque Valencia nunca tuvo una frontera física y política directa con el reino de Granada, ya que entre ambos se interponía Murcia, las propias características geográficas y humanas del territorio murciano, siempre tan falto de gente, propiciaron y permitieron que las incursiones terrestres de los almogávares granadinos llegaran sin excesivos problemas a donde se lo propusieran del reino de Valencia, incluso a los alrededores de la propia capital, como Paterna, o a Xàtiva, Cocentaina, Alcoy, etc. sin ser molestados en numerosas ocasiones.

La incorporación al reino de Valencia por Jaime II de las tierras que configuraron la procuración de Orihuela, luego transformada en gobernación, hizo que estas comarcas, hasta entonces murcianas, siguieran siendo objetivo preferido de los jinetes granadinos. La distancia física entre Granada y Orihuela o Elche siguió siendo la misma, pero ahora dependían del monarca aragonés y el entorno político en el que se iban a mover sus habitantes en sus relaciones con Granada sería diferente, pues ya no formarían parte de la política y estrategia castellana con el reino de Granada, sino de la aragonesa ${ }^{18}$.

17 TORRES FONTES, J., La actividad bélica granadina en la frontera murciana, pp. 722-723.

18 FERRER I MALLOL, M․T., Organització i defensa d'un territori fronteres. La governació d'Oriola en el segle XIV, Barcelona, 1990; "La Batllia general de la part del regne de València dellà Xixona», Anales de la Universidad de Alicante. Historia Medieval, 6 (1987), pp. 279-309. 
Por otra parte, aunque la revuelta de 1264-1265 redujo notablemente la población mudéjar en el reino de Murcia, en la zona anexionada por Jaime II quedó una importante masa de población musulmana en Elche, Crevillente, las huertas de Orihuela y Alicante, así como en el valle de Elda, donde fueron mayoría hasta $1609^{19}$, si bien la guerra de 1296-1304 hizo que su número disminuyera, por muerte, cautividad o emigración, como también sucedió con las incursiones granadinas de 1304, 1331 y 1332. Ello no fue óbice para que los cristianos siguieran viéndolos con recelo y considerándolos como una peligrosa quinta columna, colaboradora de granadinos y marroquíes en sus algaradas, siendo los moros de las comarcas alicantinas costeras o del interior, desde La Marina al valle del Vinalopó, los que peor fama gozaban, como más tarde en la segunda mitad del siglo XV sucedería con los de Monforte ${ }^{20}$. Todas las tierras situadas dellà Sexona eran consideradas por las autoridades como una zona de alto riesgo con relación a los mudéjares, dada la posibilidad de éstos de huir hacia Granada o al Norte de Africa, como hacían muchos cautivos que querían escapar de sus dueños, o simples moros libres que marchaban clandestinamente a tierra de sus correligionarios para poder vivir el Islam $\sin$ trabas $^{21}$. Para evitar tales huidas y la colaboración con espías y salteadores los monarcas limitaron la libertad de movimientos de los mudéjares en todas estas comarcas del mediodía valenciano, debiendo circular con el oportuno salvoconducto real y por los itinerarios expresamente indicados, so pena de caer en cautividad.

A la hora de reconstruir la actividad bélica granadina en la frontera meridional valenciana en estos años finales del siglo XIII y comienzos del XIV tropezamos también con la escasez de fuentes, al no existir documentación municipal de la época, y tener que recurrir sobre todo a la de la cancillería real. Granada nunca tuvo un ejército regular de forma continuada para llevar a cabo una política ofensiva contra Castilla y menos contra Aragón, con quien no tenía frontera directa, pero desde las bases orientales de Baza y Vera podía lanzar sus cabalgadas y correrías sobre territorio murciano y valenciano. En la cabalgada participaban jinetes y peones en número superior al millar, y el objetivo era siempre la destrucción de cuanto encontraran a su paso, desde la tala de cosechas a la quema de caseríos, pero sobre todo, el botín, en particular el ganado, y los cautivos cristianos. Sólo en una ocasión, con el caudillo Ridwan, como veremos, se puso sitio a Guardamar y Elche, ya que la lejanía de las bases y los problemas de intendencia impedían una acción de mayor envergadura ${ }^{22}$.

19 FERRER I MALLOL, Ma ${ }^{a}$.T., La frontera amb l'Islam en el segle XIV. Cristians i sarraïns al País Valencià, Barcelona, 1988, p. 5; Les aljames sarraïnes de la governació d'Oriola en el segle XIV, Barcelona, 1988.

20 FERRER I MALLOL, M'a.T., La frontera amb l'Islam en el segle XIV. Barcelona, 1988. Dedica todo el capítulo 2 al tema de la quinta columna, analizando el sentimiento de solidaridad panislámica, las dificultades de la convivencia cristiano-musulmana y el ataque a las morerías del reino, el control de acceso a los castillos o la libertad de movimientos.

21 FERRER I MALLOL, Ma.T., Els sarrains de la Corona catalano-aragonesa en el segle XIV. Segregació i discriminació, Barcelona, 1987.

22 TORRES FONTES, J., La actividad bélica granadina en la frontera murciana, p. 728. 
A favor de los invasores jugaba el vacío demográfico del territorio, que permitía su paso por el reino de Murcia sin encontrar resistencia, o la colaboración, más o menos interesada, de los mudéjares valencianos, que actuaban como informadores y espías de sus correligionarios granadinos. Los cristianos tenían también sus agentes de información en tierras de Granada, pero a menudo eran falsas o tardías. Esta falta de información y el factor sorpresa, eran decisivas en el éxito de las correrías granadinas, junto con la tardía reacción cristiana, ya que para cuando se habían organizado y preparado para la acción ofensiva las milicias concejiles de Elche u Orihuela, los granadinos ya habían huido con su botín, y pocas veces conseguían derrotarles y recuperar lo perdido.

Realmente podemos afirmar que conocemos con precisión casi diaria los detalles de las relaciones de la Corona de Aragón con el reino de Granada desde el reinado de Jaime II y el resto del siglo XIV gracias a los trabajos de María Teresa Ferrer i Mallol, el más importante de los cuales en esta temática lleva por título La frontera amb l'Islam en el segle XIV. Cristians i sarraïns al País Valencià (Barcelona, 1988), así como los de su equipo de trabajo y de Manuel Sánchez, cuya tesis doctoral versó precisamente sobre la Corona de Aragón y Granada ${ }^{23}$, en la Institució Milà i Fontanals del C.S.I.C. en Barcelona. El panorama general que nos ofrece el reinado de Jaime II es el de una alternancia de paz y guerra en la zona de frontera, mantenido mediante una frágil paz que se renovaba con un sistema de treguas de duración quinquenal, que formalmente respetaban las partes interesadas, aún cuando en ocasiones no surtía pleno efecto hasta que los pequeños asuntos pendientes entre las partes no estuvieran del todo solucionados. Por otra parte, no olvidemos que la agresividad y la violencia era algo habitual en la sociedad de la época, que afectaba a todos los estamentos sociales, y que en el caso de la frontera y de la guerra contra el musulmán, contra el infiel, ofrecía posibilidades de promoción social, a través del beneficio obtenido por la guerra, el golpe de mano o el corso.

Del detallado análisis realizado por Ferrer i Mallol de las relaciones de la Corona de Aragón con Granada durante el reinado de Jaime II conviene destacar el establecimiento de una alianza entre Aragón y Granada frente al enemigo común castellano en 1296, a la vez que mantenía buenas relaciones con el sultán marroquí. Pero en 1304 la alianza concertada entre Granada y Castilla dio paso a una serie de incidentes con Aragón, que acabaron en el ataque granadino-marroquí de agosto-septiembre al Sur del reino de Valencia, cuyos episodios más notables fueron el sitio durante tres días, destrucción e incendio de Cocentaina y el saqueo de Alcoy, sin que los cristianos pudieran ofrecer una mínima capacidad ofensiva, limitándose a resistir hasta que Jaime II pudiera organizar el ejército en Valencia. Para entonces los granadinos estaban de regreso a sus bases con un cuantioso botín y, lo que era más novedoso, con numerosos musulmanes valencianos (de Xàtiva, Gandía, Jávea, Orihuela, Alicante)

23 La bibliografía sobre el tema es muy extensa y remito al estudioso al prólogo que le dedica $M^{a}$.T. Ferrer i Mallol en su libro La frontera amb l'/slam, o al $n^{\circ} 4$ de la serie «Miscel.lània de Textos Medievals", 4, titulado La frontera terrestre i maritima amb l'/slam, Barcelona, 1988. 
que, galvanizados en su sentir islámico, marcharon con ellos al reino de Granada, aunque aquí las cosas no fueron tan fáciles como esperaban y muchos de ellos regresaron más tarde a sus hogares valencianos tras conseguir el perdón real.

En años sucesivos las alarmas de ataques granadinos a la frontera valenciana menudearon, por suerte la mayoría de las veces infundadas, restableciéndose la paz, alterada ocasionalmente por las capturas por ambos bandos y definitivamente con la cruzada contra Almería en 1309, concluida, tras su fracaso, con un armisticio en diciembre de este año. Las comarcas dellà Sexona no se vieron afectadas directamente por las hostilidades, pero Alicante y Orihuela sirvieron como bases de aprovisionamiento al ejército de Jaime II.

En los años siguientes toda la frontera meridional valenciana vivió un continuo rosario de incidentes, donde los rumores corrían tanto como los jinetes granadinos, los que parecen tener mejor fortuna en sus golpes de mano, en los que obtienen cuantioso botín de hombres y ganado, generando una abundante correspondencia entre Jaime II e Ismail de Granada, en la que el primero le mostraba sus quejas por todos estos ataques, aunque sin conseguir resultados apreciables, lo que dio lugar a la autorización concedida en 1315 por el rey al Consell de Orihuela a tomar represalias contra Granada. Esta será la tónica general durante el resto del reinado de Jaime II, la de una política de treguas, que generó un continuo trasiego de embajadores y mensajeros entre ambas cortes, alterada por toda clase de incidentes fronterizos, imposibles de evitar, por más que Jaime II buscara en todo momento mantener la paz. Su hijo, Alfonso el Benigno, cambiaría esta política por otra abiertamente hostil, de guerra hacia Granada, en alianza con Castilla. Pero el abandono de la coalición por parte de Alfonso XI dejó sólo al monarca aragonés frente a Granada, que supo aprovechar esta coyuntura para lanzar sus jinetes contra la gobernación de Orihuela. Las tropas del caudillo Ridwan en sus campañas de 1331 y 1332 contra Guardamar y Elche causaron enormes daños en todo el territorio, desde el saqueo de la primera, al impresionante botín de cautivos, ganado, y, sobre todo, la huida de numerosos musulmanes de Elche y del valle de Elda, de forma voluntaria o forzada, a Granada con el ejército nazarita. Esta incursión, la más audaz e importante de todas las llevadas a cabo por Granada en tierras valencianas, causó tal impacto en la memoria colectiva de sus gentes, que 130 años después, en 1461, las autoridades de Elche, ante la inquietud desatada en el territorio a raíz de la revuelta catalana, solicitan refuerzos a la reina y le recuerdan el ataque de Ridwan (Reduán) a la villa, aunque ahora se exageran las cifras y se dice que fueron 150.000 los atacantes, que además tuvieron que huir con grandes pérdidas causadas por los ilicitanos, algo que estuvo muy lejos de la realidad, pero que queda como un ejemplo más de manipulación histórica al servicio de la comunidad local y de sus intereses inmediatos, que en este caso no era otro que el conseguir ayuda militar de la señoría ${ }^{24}$.

24 HINOJOSA MONTALVO, J., “Cristianos, mudéjares y granadinos en la Gobernación de Orihuela», Relaciones exteriores del reino de Granada. IV Coloquio de historia medieval andaluza, Almeria, 1988, pp. 323-341. 
La frontera con Granada no fue sólo terrestre sino también marítima, y el mar sirvió de eje articulador a unas activas relaciones comerciales entre los reinos de Valencia y Granada ${ }^{25}$, pero también a las acciones de carácter bélico, como por ejemplo la cruzada contra Almería, y sobre todo a la actuación de los piratas y corsarios de uno $u$ otro reino. Digamos que no todos los historiadores están de acuerdo en el concepto de frontera marítima, dado que su carácter es diferente al de la terrestre, ya que si aquí vencieron los cristianos, en el mar la piratería arrinconó a los cristianos peninsulares, por lo que el concepto ideológico de frontera no es aplicable en sentido globalizador ${ }^{26}$.

En esta frontera litoral, que además de geográfica era también ideológica, como ya señalé en otro trabajo específico sobre el tema ${ }^{27}$, las relaciones entre Granada y la Corona de Aragón eran las que marcaban la dinámica de la presencia de piratas granadinos en las costas valencianas, siendo precisamente durante el reinado de Jaime II cuando la monarquía aragonesa prestó mayor atención al tema. Desde principios del siglo XIII la marina musulmana carecía de poder en el área del Mediterráneo occidental y entre 1295 y 1330 el dominio fue claramente cristiano, en concreto de la Corona de los países ribereños de la Corona de Aragón, aunque tras la cruzada de Almería fue perdiendo importancia. Pero el esfuerzo posterior de la cruzada contra Granada entre 1329 y 1333, así como de la campaña del Estrecho, que gravitó en buena medida sobre las arcas valencianas, dejó la capacidad marítimo-militar ofensiva de la marina catalana y valenciana bastante debilitada, aunque quedó claro que tampoco los musulmanes pudieron imponer su dominio en el mar. Lo que hicieron fue cambiar de estrategia, comenzando a partir de ahora una intensa campaña de desgaste de las costas cristianas, en particular las valencianas, mediantes acciones depredatorias de piratería ${ }^{28}$.

A finales del siglo XIII la marina musulmana en el Mediterráneo occidental había quedado arrinconada al área del Estrecho de Gibraltar y la superioridad naval de la Corona de Aragón fue clara, en particular en la etapa entre 1295 y 1330, que es la que aquí nos interesa ${ }^{29}$. El punto final, el de arribada, fue el control del Estrecho por los cristianos, desplazando a los musulmanes. La contrapartida fue el desarrollo de la piratería islámica.

En estos años de Jaime II en el ámbito marítimo hubo una alternancia del uso de

25 HINOJOSA MONTALVO, J., "Las relaciones entre los reinos de Valencia y Granada durante la primera mitad del siglo XV», Estudios de Historia de Valencia, Valencia, 1978, pp. 91-160; “Armamento de naves y comercio con el reino de Granada a principios del siglo XV", V Coloquio de Historia Medieval de Andalucía, Córdoba, 1988, pp. 643-658; "Las relaciones entre Valencia y Granada durante el siglo XV", Estudios sobre Málaga y el reino de Granada en el $V$ Centenario de la conquista, Málaga, 1988, pp. 83-111; RUZAFA GARCÍA, M., "Las relaciones económicas entre los mudéjares valencianos y ef reino de Granada en el siglo XV", Relaciones exteriores del reino de Granada. IV Coloquio de Historia Medieval Andaluza, Almería, 1988, pp. 343-382.

26 DÍAZ BORRÁS, A., Los orígenes de la piratería islámica en Valencia, pp. XIV-XV.

27 HINOJOSA MONTALVO, J., "La frontera marítima (ss. XIII-XV)», Actas del Congreso: La frontera: sujeto histórico, Lorca, 1994. En prensa. 
la diplomacia y de la fuerza, proliferando los incidentes de piratas y corsarios cristianos contra los musulmanes, aunque en ningún momento afectaron a los intercambios mercantiles, coexistiendo las flotas comerciales con los barcos corsarios. El objetivo fueron, sobre todo, las escuadras y barcos musulmanes del Norte de Africa y Granada, aunque no podemos hacer un balance detallado de tales actividades. Recordemos, por ejemplo, la captura en 1305 por un leño del conde de Ampurias de 32 granadinos, que fueron vendidos en Castellón, y que fueron devueltos al rey de Granada por Jaime II tras largas negociaciones. Para evitar violaciones de este tipo a las treguas vigentes el rey de Aragón ordenó armar dos leños y una barca, mandada por el valenciano Pere de Ribalta, contra los corsarios catalanes ${ }^{30}$.

Sin embargo, como señala Dufourcq, en el periodo 1310-1330 se percibe un cambio de tendencia en la actitud de marina catalana hacia los paises ribereños musulmanes, sobre los cuales no supo o no pudo mantener la presión marítima adecuada, a la vez que iba emergiendo la marina nazarí. A ello se sumaban otros factores, como el cambio de prioridades en la política exterior de Jaime II, más orientada hacia las islas italianas del Mediterráneo central, igual que los corsarios catalanes, o el abandono de posiciones comerciales por los mercaderes catalanes frente a los italianos. Lo cierto es que desde 1311 las galeras ceutíes se atreven a perseguir a barcos de la Corona de Aragón, en tanto que Barcelona y Valencia deben armar en 1314-1315 embarcaciones para vigilar los mares y perseguir a los piratas, lo que antes no había sucedido, y que era el signo de los nuevos tiempos que se avecinaban. En adelante serian los corsarios valencianos quienes se encargarían de vigilar y proteger las aguas de nuestro litoral de unas embarcaciones musulmanas cada vez más audaces en sus golpes de mano, como lo prueba el ataque y saqueo por la armada nazarí en 1304 de Vila Joiosa, cautivando a más de doscientos vecinos ${ }^{31}$, prosiguiendo a Denia y destruyendo antes el arrabal de Jávea. Por fortuna para los valencianos de la época se trató de un hecho puntual en el espacio y el tiempo, aunque durante todo el reinado de Jaime II no faltaron los avisos y rumores sobre la preparación de armadas granadinas para lanzarse sobre las costas meridionales del reino de Valencia.

28 DÍAZ BORRÁS, A., Problemas marítimos de Valencia a finales de la Edad Media: el corso, la piratería y el cautiverio en su incidencia sobre la dinámica económica: 1400-1480, Valencia, 1988. Editada en microficha; Los origenes de la pirateria islámica en Valencia. La ofensiva musulmana trecentista y la reacción cristiana, Barcelona, 1993.

29 El tema lo analizó en profundidad, en numerosos trabajos, DUFOURCQ, Charles-Emmanuel, entre ellos: L'Espagne catalane et le Maghrib aux XIlle et XIV siècles. De la bataille de las Navas de Tolosa (1212) à l'avènement du sultan mèrinide Abou-t-Hasan (1331), Paris, 1966. Hay versión cata* lana: L'expansió catalana a la Mediterrània occidental, segles XIII i XIV, Barcelona, 1969. Los planteamientos de Dufourcq son los seguidos por DÍAZ BORRÁS, A., Los orígenes de la piratería islámica en Valencia, pp. 9-32. Contiene un apéndice bibliográfico muy útil para el tema.

30 FERRER I MALLOL, Mํ.T., La frontera amb I'Islam en el segle XIV, pp. 92-93, donde analiza estos incidentes con detalle.

31 FERRER I MALLOL, Ma.T., La frontera amb /'Islam, pp. 17-72; TORRES DELGADO, C., «El Mediterráneo nazarí: diplomacia y piratería. Siglos XIII-XIV", Anuario de Estudios Medievales, 10, (1980), pp. 227-235; DÍAZ BORRÁS, A., Los orígenes de la piratería islámica en Valencia, pp. 29-30. 
Los actos de piratería comenzaron a dejar sus huellas en la población del mediodía valenciano, perceptible en el aumento del odio hacia los musulmanes, acusados de colaboracionismo con el enemigo, del miedo que se fue difuminando por la sociedad cristiana, temerosa de posibles ataques marítimos y víctima ya habitual de las cabalgadas por tierra, sin olvidar la terrible secuela del problema de los cautivos, una constante en esta sociedad de frontera, que llevó a crear en Valencia una institución específica dedicada a las redención de aquellos que eran capturados en el mar ${ }^{32}$.

Cuando finalice el reinado del rey Justo la frontera marítima de Valencia con Granada habrá experimentado cambios importantes con relación a finales del siglo XIII, cuando los marinos catalanes imponían su fuerza por el Mediterráneo occidental, siendo la aparición de la piratería musulmana, todavía modesta, y el creciente potencial de la escuadra granadina los dos rasgos más sobresalientes. Sus efectos se dejarían sentir en años sucesivos y cuando en 1331 Guardamar fue asaltada y saqueada se vio la precariedad de las defensas del flanco sur valenciano y la necesidad de controlar el área del Estrecho. Este sería el principal problema a resolver por los sucesores de Jaime II.

\section{LAS REPERCUSIONES SOCIO-INSTITUCIONALES DE LA VIOLENCIA FRONTE- RIZA}

La existencia de una frontera, aunque indirecta desde el punto de vista físico, pero real desde la percepción de las gentes de la época, tuvo importantes repercusiones en todo el mediodía valenciano y en facetas tan diversas como la demografía o las instituciones.

En primer lugar sobre las gentes residentes en el territorio, cristianos y musulmanes. Estos últimos, como ya dijimos, vieron descender su número de forma considerable en la procuración de Orihuela desde el reinado de Jaime II, aunque ya existía el precedente de la revuelta de 1264-1265. La guerra de conquista de Jaime II no hizo sino agravar el problema entre 1296-1304, y un testimonio coetáneo era muy claro al señalar que «por razón de las guerras e de los otros males que son acaescidos en tierra de Murcia, la mayor parte de los moros son muertos e los otros fuydos, por las quales cosas la tierra es muy despoblada e menguada dellos» ${ }^{33}$.

Las capturas de los almogávares, la emigración legal, o la huida con los ejércitos granadinos provocaron un lento pero continuado descenso de la población musulmana en las principales villas, como fue el caso de Orihuela, Alicante o Elche. El vacío que dejaban los mudéjares en el campo iba siendo colmado poco a poco por los nuevos repobladores cristianos, que se iban instalando en algunas alquerías abandonadas.

32 DÍAZ BORRÁS, A., “Notas sobre los primeros tiempos de la atención valenciana a la redención de cautivos cristianos (1323-1399)", Estudis Castellonencs, 3 (1986), pp. 337-354.

33 TORRES FONTES, J., "Los mudéjares murcianos en el siglo XIII", Murgetana, XVII, (1961), p. 27. Reproduce la cita FERRER I MALLOL, Mํ.T., La frontera amb l'Islam en el segle XIV, p. 6. 
Simultáneamente, las acciones depredatorias de los granadinos en tierras valencianas crearon entre los cristianos un sentimiento de declarada hostilidad hacia los musulmanes, acusados, muchas veces. con fundamento, de connivencia con sus correligionarios, en tanto que los sentimientos de solidaridad panislámica afloraban periódicamente entre los moros valencianos, sobre todo cuando triunfaban los granadinos. La libertad de movimientos para los musulmanes al sur de Jijona o las violencias contra algunas morerías fueron algunas de las inmediatas consecuencias de tan enrarecido clima. El tema lo ha estudiado muy bien $\mathrm{M}^{\mathrm{a}}$. T. Ferrer i Mallol y no insistiré en é $\left.\right|^{34}$.

A pesar de las treguas oficiales, la beligerancia impregnó continuamente la frontera con el Islam, haciendo que la agresividad y la violencia fueran componentes vitales de muchas de sus gentes. La depredación era para muchas de ellas un modo de vida ordinario, una profesión y en la frontera se acogían todo tipo de rufianes y delincuentes, a los que muchas veces se les perdonaban sus delitos a cambio de que se instalaran en aquellas tierras peligrosas. Fue en estas tierras del mediodía valenciano el escenario por excelencia del delito de «plagi» o "collera», consistente en la captura de personas que luego eran vendidas como cautivas o rescatadas a cambio de dinero. Era una actividad a la que se dedicaban habitualmente los almogávares, el otro grupo humano que destacaba por su profesionalidad en la guerra, y que cuando no participaba en las expediciones oficiales contra tierras granadinas se dedicaba al saqueo de las mismas por su cuenta, en busca de cautivos, ganado o cuanto le pudiera reportar un beneficio económico ${ }^{35}$, aunque también podía realizar tareas oficiales, como actividades de espionaje, atalaya, escuchas o correos. Estos microgrupos humanos tenían un funcionamiento directo y espontáneo, de pequeños grupos entre diez y quince hombres, comandados por un almugatèn o un adalid, y los encontramos por igual en Valencia, Murcia o Granada.

Esta violencia fronteriza tenía sus principales víctimas entre los habitantes de estas comarcas o los que transitaban por ellas. La inseguridad, la amenaza a perder la libertad, fue una constante durante toda la baja Edad Media entre las gentes de la gobernación de Orihuela, que debieron acostumbrarse a vivir acompañados de ella, y tanto a título personal, desde el agricultor y el pastor al pescador, como colectivo, como fue el caso de poblaciones enteras como Vila Joiosa o Guardamar que sufrieron sus consecuencias en toda su crudeza. La caída en cautiverio fue la tribulación más penosa con la que debieron enfrentarse las gentes de la época, a ambos lados de la frontera, por supuesto, generando un flujo cotidiano de cautivos y de gentes que acudían a su rescate.

La proximidad de Granada y la vecindad del de Murcia hizo que el espacio meridional valenciano hubiera de organizarse para la guerra. Fue en estas comarcas don-

34 FERRER I MALLOL, M‥T., La frontera amb I'Islam en el segle XIV, capítulo 5. pp. 17-46.

35 FERRER I MALLOL, M ${ }^{a}$. . ., La frontera amb l'Islam en el segle XIV, capítulo 3, pp. 47-72; Organització i defensa d'un territori fronterer. La governació d'Oriola en el segle XIV, Barcelona, 1990. dedica el capítulo 7 a los almogávares. 
de se registró una mayor actividad bélica en estos siglos, tanto frente a cristianos como a musulmanes, desde la revuelta mudéjar del siglo XIII a la guerra de Castilla en 14291430 , y pocas villas resultaron tan castigadas como Alicante u Orihuela por estos conflictos. La mayoría de los conflictos medievales se reducían a operaciones limitadas en el espacio y en el tiempo, dada la lentitud de avance de los atacantes y la defensa a ultranza de los atacados. De ahí la importancia de mantener un buen sistema de murallas en las villas y que los castillos estuvieran a punto en sus instalaciones y bien avituallados de armas y provisiones.

Lo ideal hubiera sido la construcción de una sólida red de fortificaciones a lo largo de la frontera, pero ello no fue posible por la conjunción de diversos factores, como la debilidad financiera de la monarquía y los municipios, incapaces de emprender obras de envergadura de forma continuada, lo que hacía que la mayoría de los castillos de la región estuvieran en deficientes condiciones y carecieran de guarnición permanente, además de que la diversidad de poderes, el rey o los señores, impedía acciones coordinadas, y la resistencia era aislada. Eran fortalezas de origen islámico, cuyos puntos clave para la Corona de Aragón eran Orihuela y Alicante. Los monarcas fueron conscientes siempre de este papel frontero de las mismas y así lo explicitaron en su documentación, no dudando en calificarlas como "clau del regne», en particular el de Alicante ${ }^{36}$, lo que no impidió que en la guerra de los dos Pedros fueran ocupadas por el monarca castellano, Pedro I. Las alquerías dispersas por el campo eran protegidas por torres, donde se refugiaban sus habitantes en caso de peligro.

En cuanto a la fortificación de los núcleos habitados, sólo Orihuela, Elche y Alicante poseían sólidos recintos amurallados, que en otras localidades, como Guardamar, eran más débiles, lo que valió su ocupación por los granadinos, obligando a posteriores reedificaciones y modificaciones en el poblamiento.

Este clima bélico y de violencia, en particular durante el reinado de Jaime II, motivó la militarización de la sociedad fronteriza, cuyas gentes debían compartir el trabajo con las armas, estar en vigilancia permanente frente a cualquier posible acción por sorpresa del enemigo. La milicia vecinal encuadraba al individuo para las acciones ofensivas o defensivas, y en ninguna otra comarca valenciana como aquí lo militar impregnó de forma tan intensa toda la sociedad, desde el caballero, que gracias a la posesión de caballo y armas monopolizaba los cargos de gobierno municipal, al simple peón, obligado a acudir a la llamada Consell. Como premio, el botín, minuciosamente regulado su reparto, y medio de promoción social.

En cuanto a la frontera marítima, la superioridad de la marina catalana y la acción ofensiva de los corsarios cristianos hacían innecesario durante estos años de finales del siglo XIII y primeras décadas del XIV un sistema de protección costera, aunque el asalto a Guardamar en dos ocasiones demostró la debilidad defensiva en este flanco del litoral. De ahí que cuando aumente la peligrosidad de la piratería granadina y genovesa, ya en la primera mitad del siglo XIV se tome conciencia de adoptar medidas preventivas contra los barcos enemigos, erigiendo torres de defensa, aunque sin

36 HINOJOSA MONTALVO, J., La clau del regne, Alicante, 1990. 
ningún plan preconcebido o articulado, que no llegaría sino más tarde. La noticia más antigua que conozco data de 1337 cuando el infante Ramón Berenguer, señor de Elche, autorizó al Consell ilicitano a construir una torre en la isla de Santa Pola, que era considerada como un refugio para los piratas, aun cuando no se llegó a construir, pues no hay más noticias de ella ${ }^{37}$.

37 HINOJOSA MONTALVO, J., «El Cap del Aljup, puerto medieval de Elche», Homenatge a Álvaro Santamaría, Mayurqa, 23, 1989, I, pp. 311-324; DÍAZ BORRÁS, A., Los orígenes de la piratería islámica en Valencia, pp. 105-110. 